\section{Institutional Distance, Regional Clusters and Performance of Foreign Subsidiaries: Evidences from Brazil}

\author{
Jonas Fernando Petry ${ }^{\dagger}$ \\ Universidade Federal do Amazonas - UFAM, Manaus, Amazonas, Brazil \\ Mohamed Amal $\Omega$ \\ FURB/SC, Blumenau, Santa Catarina, Brazil \\ Dinorá Eliete Floriani ${ }^{¥}$ \\ Universidade do Vale do Itajai (UNIVALI), Itajaí, Santa Catarina, Brazil
}

\begin{abstract}
Institutional distance (ID) has come to be a key concept in understanding the determinant factors of the performance of a multinational company's (MNC) subsidiaries in emerging economies. However, the results of empirical studies are contradictory and inconclusive. The objective of this study is to evaluate the effects of ID on the performance of foreign firms' subsidiaries and the extent to which these effects may be mediated by locating these companies within regional clusters and by different choices of entry mode. Through a regression analysis of a sample of 308 subsidiaries of foreign firms, results show that whereas ID is negatively related with the firm's performance, locations within clusters and access to the resources afforded by economies of agglomeration have positive effects on performance. Finally, the empirical evidence indicates that access to the resources of industrial clusters moderates the effects of ID on the performance, motivating MNCs to adopt overseas entry modes for complete control.
\end{abstract}

Keywords: Institutional distance; Entry modes; Cluster resources; Performance of subsidiaries.

\section{INTRODUCTION}

Multinational companies (MNCs), in their majority, generate more volume of business abroad than in their country of origin. Therefore, performance evaluation of subsidiaries abroad plays a fundamental role in creating value (KRETSCHMER, 2008) and in the strategic management for the MNC (HAMANN et al., 2013). Despite the appeal and the various suggested evaluation approaches, research on the performance of foreign subsidiaries of MNCs has produced heterogeneous results (HENNART; SLANGEN, 2014), which may have been influenced by institutional factors (KRETSCHMER, 2008; LIU et al., 2016). They impose on foreigners an environment of operation of high political uncertainty, macroeconomic instability, dysfunctional regulatory environments, and inefficient market institutions (LUIZ; RUPLAL, 2013). In this article, we will describe this institutional environment through the concept of ID, which measures regulatory, normative, cognitive and cultural differences between the country of origin and the host country of the MNC (KOSTOVA, 1997).

\footnotetext{
Corresponding author:

† Universidade Federal do Amazonas - UFAM, Manaus, Amazonas, Brazil.

E-mail: jonaspetry@brturbo.com.br

${ }^{\Omega}$ FURB/SC, Blumenau, Santa Catarina, Brazil.

E-mail: mohamedamal.amal@gmail.com

$¥$ Universidade do Vale do Itajaí (UNIVALI),

Itajaí, Santa Catarina, Brazil.

E-mail:dinora@univali.br
}

Received: $12 / 28 / 2016$

Revised: 10/09/2017.

Accepted: 10/25/2017

Published Online: 04/20/2018.

DOI: http://dx.doi.org/10.15728/bbr.2018.15.3.6 
Such an environment can subject multinationals to countless risks and challenges that can adversely affect the survival and volume of their activities abroad (ZAHEER; MOSAKOWSKI, 1997; SLANGEN; BEUGELSDIJK, 2010). Companies can respond to this complex institutional environment in different ways. They can adjust or even change their own international entry mode strategies when operating in host countries (ROOT, 1994).

On the other hand, MNCs can adopt a location-oriented strategy, establishing their subsidiaries abroad within regional clusters (GHOSHAL; NOHRIA, 1989; ZAHEER, 1995) for benefiting from access to spillovers (ZHANG; LI; LI, 2014), that is, relational-based shared resources (BOSCHMA, 2005; LAZZERETTI; CAPONE, 2016; PRIM; AMAL; CARVALHO, 2016). The different externalities, or location resources, can contribute to mitigating the effects of ID and provide incentives for entry modes based on wholly owned subsidiaries (HOSPERS; BEUGELSDIJK, 2002) and, consequently, achieve better performance. Therefore, we suggest that the greater the access to the location resources, the greater the likelihood of developing knowledge skills to deal with the liability of foreignness (LOF), reducing transaction costs and thus helping to mitigate the adverse effects of ID. On the other hand, we understand that MNCs cannot always establish their subsidiaries in a regional cluster. In this case, they can deal with foreign direct investment (FDI) by choosing the entry mode for example.

In the light of institutional theory and the regional cluster, we propose to investigate the following research questions: what are the effects of ID on the performance of foreign subsidiaries? To what extent can such effects be moderated by the location of industrial clusters and by the choice of entry mode?

Previous studies have highlighted the effects of ID on the performance of foreign subsidiaries operating in developing countries (TANG; ROWE, 2012; AMBOS; HÅKANSON, 2014). However, most studies have focused on the scope of country analysis, and less attention has been paid to understanding the impacts of ID in different national regions. Thus, we propose the existence of a mechanism of interaction between the national and subnational levels in terms of how foreign companies deal with ID. When making the choice to locate the subsidiaries in a specific host country, MNCs are aware of the constraints and related costs, and there is no set of strategies that can be developed to mitigate such limitations. The decision to locate the subsidiary in a regional cluster can be understood as a strategic response to the additional costs MNCs face at the national level. This is particularly the case with large host economies, such as Brazil, where regional differences in level of development and cultures are evident. A regional cluster is known for the spatial concentration of companies. This environment allows foreign subsidiaries to access agglomeration externalities and, consequently, provide the necessary resources to mitigate the effects of institutional distance.

In this article, we intend to contribute to this debate in various ways: first, to examine the mechanisms by which foreign subsidiaries can mitigate the effects of ID on performance. Subsequently, we suggest that such mechanisms may be related to the entry mode or to the location of the subsidiary in a regional cluster. Third, we consider that there is a process of interaction between the two mechanisms in the formation of the relationship of ID \& performance. We test these propositions for the case of Brazil, for the regional dynamism, as it presents a large economy and for being the fifth host economy of FDI flow (62 billion USD in 2014) (UNCTAD, 2015), which makes this research adequate. Finally, we collected data from a significant number of foreign subsidiaries operating in different regions of the country.

In addition to the introduction, we divide this article into five more sections. We devote section 2 to reviewing the literature and developing the hypotheses. In section 3 we present 
BBR

15,3

304

the methodological procedures. In section 4, we present and discuss the main results. Section 5 presents the considerations and limitations of the research, followed by references.

\section{LITERATURE REVIEW AND HYPOTHESES}

\subsection{Determinants of Performance}

A considerable volume of research on international business (IB) has focused on assessing the performance determinants of MNCs subsidiaries (LARIMO; LE NGUYEN; ALI, 2016). Most of the studies attempted to explain the relationship between the degree of asset impairment and performance using a variety of theories and arguments applied to certain types of subsidiaries strategies in the host country (FISCH, 2012). Two main approaches support empirical studies on the performance of foreign subsidiaries. The first one originated in the economic tradition, emphasizing the importance of external market factors to determine the success of a company. The other approach is based on sociological and behavioral paradigms and sees the organizational factors and the ability to adapt to the environment as the main determinants of success (HANSEN; WERNERFELT, 1989).

However, the performance determinants from the two streams have produced ambiguous results. In addition, there is no consensus on the conceptualization and measurement of construct performance (ROSENBUSCH; RAUCH; BAUSCH, 2013). Empirically, the construct is represented by the common variance of different dimensions (MILLER; WASHBURN; GLICK, 2013), such as objective and subjective performance, or even using different measures of performance due to the multidisciplinary perspective of the field of IB research (LENZ, 1981). In view of the breadth and complexity of the theme, this study delimits the concept of performance and circumscribes only the scope of the discussion in the field of IBs and in matters of their subjective measurement.

\subsection{Institutional Distance and Performance}

The idea of costs when doing business abroad is an established concept in IBs that stems from the additional disadvantages supported by the MNCs in which local enterprises in a host country do not incur (EDEN; MILLER, 2004). The concept of cost in IBs culminated in a second concept due to the lack of familiarity with the environment, disseminated by Zaheer (1995) as the LOF, which originates from limited local knowledge, the local discriminatory attitudes of stakeholders and the management difficulties of organizations whose subunits are separated by time and distance (NACHUM, 2014). This argument holds that foreign subsidiaries must overcome the LOF to survive in a host country, adapting their organizational practices to local norms to gain legitimacy (ROSENZWEIG; SINGH, 1991). The LOF requires management capacity from enterprises resulting from geographic distance to mitigate the costs of unfamiliarity with economic policies, cultural differences, institutional environment among other factors that bring additional costs in the host country of the foreign subsidiaries (ZAHEER, 1995). Consequently, the subsidiaries of MNCs are prone to meet the demands of the host country environment. In this regard, Kostova (1997) developed an ID concept referring to measures of dissimilarity between the regulatory, cognitive and normative institutions of the host countries and country of origin of the MNC.

Institutional theory provides a non-economic explanation of organizational behaviors and strategies (SCOTT, 2014). Institutions regulate economic activities by defining the rules of the game as a basis for production, exchange and distribution (YANG; SU, 2014). The institutional environment is the main determinant of the structure and behavior of the company (DIMAGGIO; POWELL, 1983), in which institutional forces are the social and legal environments that affect the perceptions and decisions of decision makers (SCOTT, 
2014). Thus, institutional theory provides valuable assumptions that allow theorizing multiple levels of analysis and examining critical issues for MNCs in the international market (KOSTOVA; ROTH; DACIN, 2008). Therefore, institutional theory is the basis of ID for understanding the institutional environment as a determining factor in the structure and performance of the subsidiary abroad (SCOTT, 2014).

Empirical studies have found mixed results. In essence, investigations analyzed the differences of institutions between countries and employ objective or subjective measures of performance. One of the main conceptual dilemmas of international management has been the issue of ID that negatively influences the performance of the subsidiary (LU; BEAMISH, 2001). This argument suggests that we test the following hypothesis:

$\boldsymbol{H}_{1}$ : The greater the distance between countries, the greater the dissimilarity between the institutions and, consequently, the lower the performance of the foreign subsidiaries in the host country.

Even with controversial results, the effect of ID on the performance of subsidiaries abroad is still a crucial issue in IBs. MNCs can adopt different strategies to deal with the additional constraints and transaction costs they have to face when they enter emerging economies. Usually, the decision on entry mode relates to the institutional differences between two countries (BERRY; GUILLÉN; ZHOU, 2010). The choice of entry mode is a response to the implications of ID.

\subsection{Entry Mode and Performance}

International expansion in emerging markets requires consideration of the entry choice adopted by MNCs. The entry mode is the organizational form adopted by the MNC to enter a host country. It refers to the characteristics of an organization that identifies it as a distinct unit (LI; YANG; YUE, 2007). It is the identity defined in terms of social codes that specifies the ownership and control of an entity. Thus, the entry of MNCs into the host country is based on the capital involved and the strategy adopted, which may be a jointly controlled entry, through a joint venture, or the entry through full control of the subsidiary via greenfield (LI et al., 2007).

The different types of entry modes (ownership and control) in international markets relate to the ID between two countries (ZAHEER, 1995; LUIZ; RUPLAL, 2013). Thus, choosing the entry mode requires careful analysis of the impact of institutions on the grounds of differences between countries (KOSTOVA, 1999), which consequently entails additional costs. Empirical research has shown that the choice of entry mode has critical implications for the performance of subsidiaries. If the costs of doing business or the effects of ID beyond the border are low, the MNC will adopt more representative capital entry strategies (greenfield). However, if the distance between countries implies increases in the monitoring of opportunistic behaviors, high costs of adaptation, among others, the MNC will prefer an internal governance structure with less representative capital entry strategies (joint venture) (ZHAO; LUO; SUH, 2004; LUIZ; RUPLAL, 2013). Thus, higher performance targets may lead to the MNC assuming greater risk and, thus, greater resource commitment in the entry mode strategy (SHRADER; OVIATT; MCDOUGALL, 2000). Thus, the following hypotheses are established:

$\boldsymbol{H}_{2}$ : Whole entry mode strategies tend to perform better in relation to joint venture entries.

$\boldsymbol{H}_{3}:$ In the greenfield entry mode, subsidiaries' performance is inferior than the joint venture entry mode. 
BBR

15,3

Different studies have found strong associations between the entry mode and the performance of foreign subsidiaries operating in developed and developing countries. In large part, however, these relations reflect the institutional and cultural differences between the country of origin and the host country of the subsidiary (LIAO, 2015). On the other hand, the entry mode is a dimension that can ultimately be determined, by the institutional regulatory system of the host country (SURDU; MELLAHI, 2016), or it may reflect the company's preference on how to manage its value-added activities in all countries (TOMIO; AMAL, 2015). This may bias the relationship between ID and performance. We suggest that locational choice at the subnational level can operate much more efficiently as a mechanism to mitigate the adverse effects of ID on performance. In particular, we suggest introducing the concept of regional clustering as a logic of localization for understanding how foreign subsidiaries can handle ID.

\subsection{Cluster Resources}

The idea of foreign subsidiaries in the host country embedded in social networks with other actors can be seen as a strategic resource. Thus, the subsidiary may have access to resources and capabilities outside the organization, such as capital, goods, services, innovations, among many other resources and factors (ANDERSSON; FORSGREN; HOLM, 2002). The insertion of foreign subsidiaries in a cluster in the host country starts from the assumption of the relations developed in the interaction of companies (HOLM; JOHANSON; THILENIUS, 2015). Resources refer to the informative or idea components that are made available by the cluster, such as access to the pool of skilled labor, inputs, specialized services and technology spillovers (MARSHALL, 1890). Porter (2009) organized the keying ideas of cluster functions in which the actors in the cluster are not necessarily just the companies. It is also made up of organizations and institutions that include industries, government agencies (national and regional), among others, such as universities or research institutions that compete, but also cooperate with each other.

Clustering strategy is an effective offensive mitigation mechanism to overcome ID (LUO; SHENKAR; NYAW, 2002). Subsidiaries benefit from knowledge externalities (BOSCHMA, 2005); consequently, the effects of ID are mitigated, and the subsidiaries will perform better. Thus, the cluster resource factors investigated were defined in terms of institutional proximity (RINST), organizational proximity (RORG), cognitive proximity (RCOG) and social proximity (RSOC), as follows: RINST are resources related to the political framework; RORG are resources related to the proximity of the actors in organizational terms; RCOG are resources related to the sharing by actors of a common space of reference and knowledge; and RSOC are resources that are associated with established social relationships between agents in the microenvironment (BOSCHMA, 2005). We, therefore, established the hypothesis that:

$\boldsymbol{H}_{4}:$ Greater access to cluster resources by foreign subsidiaries is positively related to
performance.

\subsection{Moderating Effects}

As highlighted by theory, ID has adverse effects on the performance of subsidiaries operating in emerging economies. These effects reflect higher LOF faced by companies and the high risks related to the uncertainties of operating in an environment of weak and different institutions in relation to the culture of the host country.

The success of subsidiaries depends on how they can handle the costs arising from the business environment. The success of subsidiaries depends on how they handle the costs arising from the business environment, which, in turn, can gradually reduce the implications 
of the distance between the country of origin and the host country of the subsidiaries. However, we consider that such factors can hardly unravel the complex system of distance management. We suggest, then, that the management of ID can occur through two specific mechanisms: the choice of entry mode and local selection at the subnational level. Both mechanisms can act individually but also interactively to manage the impacts of ID on the performance of subsidiaries. The moderating role derives from the configuration and scope.

The entry mode can stimulate access to the specific knowledge through a learning process, which can occur in case of cooperation or alliance with the local companies. In the case of a higher ID between the country of origin and the host country, companies are more likely to adopt joint ventures and acquisitions entry modes. This entry mode can mitigate the effect of ID, providing learning opportunities and access to specific resources that are unique to local businesses. Countries with weak institutional environments are characterized by high asymmetry in access to information and high imperfection of the market. Therefore, multinational enterprises, when operating through wholly owned subsidiaries and new companies, may encounter barriers to access the necessary knowledge and the location of limited resources to be able to compete in the host country. Thus, we formulate one more hypothesis:

H5: The entry modes by Joint Venture and Acquisition have a positive moderating effect on the relationship between Institutional Distance and Performance offoreign subsidiaries.

MNCs can also opt for a localization strategy to deal with the implications of ID. By location strategy, we refer to the different location options at the subnational level. In addition to the classic factors that may affect the location decision, companies may choose to locate their branches in a region with high industrial agglomeration, or in a region with low or no agglomeration economy. We propose that MNCs can better handle ID by locating their subsidiaries in regions that can benefit from agglomeration economies through the different externalities generated by an industrial cluster. The greater the level of agglomeration of a region, the greater the possibility for the subsidiary to access the specific resources needed to accelerate the learning process and mitigate the effects of ID.

ID is a concept that captures the transaction cost at the national level, and agglomeration economies reflect the benefits of a proximity strategy. The MNC can replace the learning process, which usually occurs by acquisition and joint ventures, by the high level of immersion in regional clusters. Therefore, the mechanism of response to ID will occur in terms of cooperation and interaction with companies and with institutions and social networks derived from the geographical proximity of companies. We, therefore, have tested the hypothesis that:

$\boldsymbol{H}_{6}:$ Greater access to cluster resources has a positive effect as an interaction factor in the relationship between ID and the performance of foreign subsidiaries.

Finally, since we consider that the two mechanisms of entry mode of regional cluster can act individually, and in an interactive way too, we will test the following hypothesis:

H7: The interaction between entry mode and access to regional cluster resources will moderate the effects of ID on the performance of foreign subsidiaries.

Figure 1 presents the general picture of the hypotheses: 


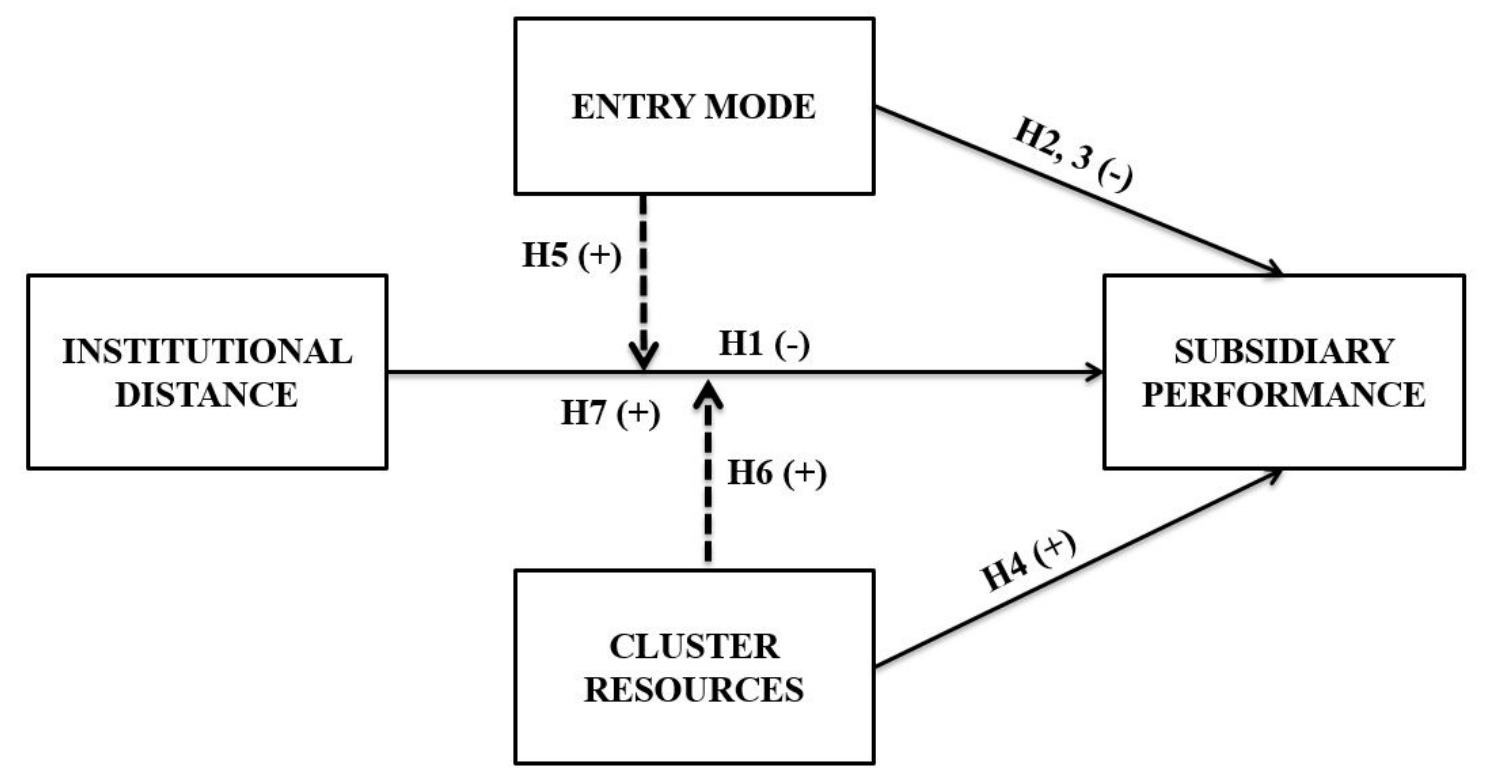

Figure 1. Conceptual Model.

\section{METHODOLOGY}

\subsection{SaMple Data ANd Description}

The sample universe of foreign subsidiaries in Brazil consists of 14,419 companies (BACEN, 2010). However, access to the name of the foreign subsidiaries that carry out productive activity in Brazil is not available. The first phase involved the construction of the framework using data gathered from the chambers of commerce of the main countries with Brazil. The second phase comprised the subsidiaries of shipping companies listed in Abeam. Finally, the subsidiaries of the listed oil and gas segments in the state of Rio de Janeiro. This process resulted in a universe of two thousand foreign subsidiaries identified in Brazil.

The sample is non-probabilistic of transversal application and comprised 333 executives of foreign subsidiaries. Twenty-five questionnaires were not completed correctly and were excluded, thus, resulting in 308 subsidiaries that comprise the total sample. $52.3 \%$ of the subsidiaries entered the country by the end of the 20th century. A Since 2001, a new FDI inflow is recorded, $47.7 \%$ of the sample, which characterizes FDI in Brazil as an activity on the rise. The average age of executives is 37.39 years, with the majority $(97.1 \%)$ of Brazilian nationality. About $54 \%$ of the subsidiaries entered the country by joint venture (168 subsidiaries) - of these, $56.09 \%$ (83) are inserted in a cluster - and $45.5 \%$ by greenfield (140); 65 subsidiaries that entered through greenfield are inserted in a cluster. Germany, Italy, France, Switzerland, USA, Japan, Spain, Denmark, Great Britain, Belgium and Portugal account for $90.3 \%$ of the investigated subsidiaries (278). Austria, Netherlands, Israel, Chile, China, Finland, Norway, New Zealand, Sweden, South Africa, Australia, Canada, Colombia, India, Ireland, Iceland, Mexico and Senegal represent 9.7\% (30). Of the total subsidiaries, 200 are from the industry sector and 108 from the service sector. The average experience of subsidiaries in Brazil is 21.33 years, which characterizes a sample with vast experience distributed in 15 Brazilian states. 


\subsection{VARIABLES}

\section{DEPENDENT VARIABLe}

The performance of subsidiaries abroad has been discussed in management and IBs literature with two different approaches. The first evaluates the implications of the performance of the MNC intangible asset perspective. The second approach focuses on the longevity of overseas subsidiaries. This perspective focuses on the argument for overcoming the competitive disadvantages of ID in relation to its counterpart (HANSEN; WERNERFELT, 1989). Nevertheless, the literature presents contradictory and inconclusive statements and results. On the one hand, research that advocates the standardization of evaluation, and on the other hand, arguments in the differentiation of the performance according to the context in the scope of the subsidiary contemplating contingent and institutional factors of the host country (KRETSCHMER, 2008). In view of the breadth and complexity of the theme, this investigation delimits only the scope of the perceptive perspective of the subjective performance of the subsidiaries in the host country.

Subjective measures may contain subjective information on financial performance. Thus, we measured the performance construct as a dependent variable through subjective perception that employed satisfaction scales with sales, market share, growth expectations, and satisfaction with profit. The performance construct was adapted from Rosenbusch et al., (2013).

\section{INDEPENDENT VARIABLES}

We based the questionnaire on empirical and theoretical studies. The entry mode used nominal variables with binary coding $(0=$ greenfield and wholly owned subsidiary; $1=$ joint venture and acquisition), adapted from Zhao, Luo \& Suh (2004). We adapted the DI construct (consisting of 6 questions) from Qian, Li \& Rugman (2013). To measure the construct of cluster resources, we used 5 dimensions: institutional proximity (RC_INST - 6 questions), organizational proximity (RC_ORG - 4 questions), cognitive proximity (RC COG - 5 questions), social proximity ( $\mathrm{RC}_{-} \mathrm{SOC}-5$ questions) and geographical proximity (RC_GEO - 4 questions), which were adapted from the theoretical study by Boschma (2005). The operationalization of the variables is represented in Table 1.

Table 1. Operation of variables.

\begin{tabular}{|c|c|c|c|}
\hline Dimension & Variable & Operationalization & Author \\
\hline $\begin{array}{c}\text { Institutional } \\
\text { Distance }\end{array}$ & $\begin{array}{l}\text { Cognitive } \\
\text { Normative } \\
\text { Regulatory }\end{array}$ & $\begin{array}{l}\text { Seven-point agreement scale (anging } \\
\text { from } 1=\text { totally disagree } 7 \text { = totally } \\
\text { agree) }\end{array}$ & QIAN; LI; RUGMAN(2013) \\
\hline $\begin{array}{l}\text { Cluster } \\
\text { Resources }\end{array}$ & $\begin{array}{l}\text { Institutional proximity } \\
\text { Organizational proximity } \\
\text { Cognitive proximity } \\
\text { Social proximity } \\
\text { Geographical proximity }\end{array}$ & Distance in $\mathrm{km}$ & BOSCHMA (2005) \\
\hline Entry Modes & Establishment and ownership mode & Nominal/dichotomous scale & $\begin{array}{c}\text { ZHAO; LUO; SUH, (2004); } \\
\text { DIKOVA; WITTELOOSTUIJN } \\
(2007)\end{array}$ \\
\hline
\end{tabular}


BBR

15,3

ID is determined according to the cognitive, normative and regulatory dimensions that involve the following approaches: (i) cost of spatial distance, including transport, coordination and administration; (ii) position of the subsidiary in the cluster and its links with local agents; (iii) costs associated with the country's lack of knowledge and skills; (iv) costs associated with cognitive, normative and regulatory diversities.

Cluster resources are determined from institutional, organizational, cognitive, social, and geographical proximity. RC_INST are associated with other forms of proximity, such as public or private support institutions (BOSCHMA, 2005; KNOBEN; OERLEMANS, 2006). RC_ORG are associated with shared relationships in an organizational arrangement (BALLAND; DE VAAN; BOSCHMA, 2013). RC_COG are based on the sharing of knowledge and competence bases (BOSCHMA; FRENKEN, 2010; MOLINA-MORALES et al., 2014). RC_SOC are based on the relationships of trust between the actors (BOSCHMA; FRENKEN, 2010). RC_GEO are related to the spatial distance between the actors (BOSCHMA, 2005; LAZZERETTI; CAPONE, 2016). The entry mode into the host country refers to the establishment strategies (greenfield or acquisition) and ownership of the subsidiaries (joint venture or wholly-owned).

\section{CONTROL VARIABLe}

We employed two control variables to discard alternative explanations between relations of interest: the subsidiary sector and experience in the host country. The objective is to exclude certain alternative reasons. The industry was based on the classification of the Global Industry Classification Standard (GICS). This classification was measured as a dichotomous variable: the industry sector $=0$ and the services sector $=1$. We measured the experience by the total years of operation of the subsidiary in Brazil.

\section{Moderating VARiables}

In this study, we used two moderation variables independently (HAIR et al., 2009). In a nutshell: Cluster resources and entry modes. For the final model, we used the two moderation variables simultaneously in the relationship between ID and performance.

We investigated and tested theoretical relationships under multivariate analysis based on the multiple linear regression technique. For this purpose, the following steps were satisfied after the descriptive analysis: (i) exploratory factor analysis (EFA); (ii) multiple linear regression (MLR); (iii) normality; (iv) linearity; (v) multicollinearity; (vi) homoscedasticity; and (vii) autocorrelation (HAIR et al., 2009). We analyzed the data with the SPSS software 23.0 according to the following equation:

$$
y_{i}=\beta_{0}+\beta_{1} \beta_{1 i}+\beta_{2} X_{2 i}+\beta_{3} X_{3 i}+\beta_{4} \text { VI.Mod } \ldots+\beta_{p} X_{p 1}+\varepsilon_{i}
$$

\section{RESULTS AND DISCUSSION}

Table 2 shows the correlation matrix. The results show low risk of multicollinearity.

We performed the normality test in the distribution of the dependent variable with the Kolmogorov-Smirnov test (K-S). The model presents a mean of 3.855, standard deviation 1.1381, K-S 0.074 and Sig. 0.000, indicating that the distribution is normal. The linearity test is represented by Pearson's R. This discussion is in the Regression Table 3, along with the multicollinearity test (VIF) and the autocorrelation test represented by the DurbinWatson test. We observed that the values meet the recommendation by Hair et al., (2009). We performed the residue homoscedasticity test through Levene's test (HAIR et al., 2009). We found only one indicator with non-homogeneous variance (RCOG - Lev. 1.580, Sig. 
Table 2. Correlation Matrix.

\begin{tabular}{lccccccc} 
Table 2. Correlation Matrix. & \multicolumn{1}{c}{ BBR } & & \\
\hline & ID & UNEMPL & RC_INST & RC_ORG & RC_COG & RC_SOC & ENTRY_M \\
\hline ID & 1.000 & - & - & - & - & - & - \\
UNEMPL & -0.133 & 1.000 & - & - & - & - & - \\
RC_INST & 0.043 & $0.179^{*}$ & 1.000 & - & - & - & - \\
RC_ORG & $-0.230^{*}$ & $0.279^{*}$ & $0.460^{*}$ & 1.000 & - & - & - \\
RC_COG & -0.066 & $0.230^{*}$ & $0.495^{*}$ & $0.477^{*}$ & 1.000 & - & - \\
RC_SOC & $0.181^{*}$ & 0.016 & $0.319^{*}$ & $0.276^{*}$ & $0.376^{*}$ & 1.000 & - \\
ENTRY_M & 0.059 & -0.092 & -0.105 & -0.146 & -0.069 & 0.061 & 1.000 \\
\hline
\end{tabular}

0.044), which would lead to the rejection of the null hypothesis of equality of variance. The other variables (ID - Lev. 0.552, Sig. 0.972; RINST Lev. 0.807, Sig. 0.692; RORG Lev. 1.256, Sig. 0.205; RSOC - Lev. 1.504, Sig. 0.087; ENTRY - Lev. 0.939, Sig. 0.930) presented p-value above 5\%, therefore, we do not reject the hypothesis of equality of variances.

\section{Model ESTIMATES AND DISCUSSION}

Table 3 presents the Durbin Watson test analysis, and reference values above 2 are recommended (HAIR et al., 2009). The linearity test is represented by R2, and R2 is desired from $3.08 \%$ to $5.54 \%$. We note that the values are below the desired values. The collinearity statistic is represented by VIF, and reference values $\leq 5$. Thus, the necessary assumptions for the realization of MLRs were met, assuming that the assumptions were not violated.

The results obtained in model 1 of Table 3 reveal that the relation of the ID in the performance is statistically significant (Sig.0.020 $\leq 0.05$ ). This means that the negative relationship with the performance of the subsidiaries is determined by the measures of dissimilarity between the institutions of the host countries and country of origin of the MNC. The result corroborates the idea that the greater the distance between countries, the worse the performance results (ZAHEER; MOSAKOWSKI, 1997). Liu et al., (2016) found similar results by among others. Thus, hypothesis $\mathrm{H}_{1}$ is confirmed.

Table 3. Regression Results.

\begin{tabular}{|c|c|c|c|c|c|c|}
\hline Variable & $\begin{array}{c}\text { Model } 1 \\
\beta\end{array}$ & $\begin{array}{c}\text { Model } 2 \\
\beta\end{array}$ & $\begin{array}{c}\text { Model } 3 \\
\beta\end{array}$ & $\begin{array}{l}\text { Model } 4 \\
\beta \text { (Sig) }\end{array}$ & $\begin{array}{l}\text { Model } 5 \\
\beta \text { (Sig) }\end{array}$ & $\begin{array}{l}\text { Model } 6 \\
\beta \text { (Sig) }\end{array}$ \\
\hline ID & $-0.133^{a}$ & - & - & $-0.097(0.112)^{\mathrm{a}}$ & $-0,452(0,000)^{a}$ & $-0.441(0.000)^{\mathrm{a}}$ \\
\hline CLUSTER RESOURCE & - & $0.245^{\mathrm{a}}$ & - & - & - & - \\
\hline ENTRY MODE & - & - & $-0.092^{a}$ & - & - & - \\
\hline Moderator 1: (ID X Entry) & - & - & - & $0.097(0.111)^{\mathrm{b}}$ & - & - \\
\hline Moderator 2: (ID X Cluster Resources) & - & - & - & - & $0.373(0.001)^{\mathrm{b}}$ & - \\
\hline $\begin{array}{l}\text { Moderator 3: [(ID X Cluster Resources) + } \\
\text { ID X entry mode)] }\end{array}$ & - & - & - & - & - & $0.357(0.001)^{\mathrm{b}}$ \\
\hline Contr_Sector & - & - & - & - & - & - \\
\hline Contr_Experience & - & - & - & - & - & - \\
\hline $\mathrm{R}^{2}$ & 0.014 & 0.057 & 0.005 & 0.019 & 0.048 & 0.044 \\
\hline ANOVA & $0.020^{*}$ & $0.000^{* * *}$ & 0.109 & $0.019^{*}$ & $0.000^{* * *}$ & $0.000^{* * *}$ \\
\hline DW & 1.964 & 2.107 & 1.971 & 1.967 & 2.062 & 2.054 \\
\hline $\mathrm{VIF}^{\mathrm{a}}$ & 1.000 & 1.000 & 1.000 & 1.157 & 3.777 & 3.947 \\
\hline VIF $^{b}$ & - & - & - & 1.157 & 3.777 & 3.947 \\
\hline
\end{tabular}

Note: ${ }^{*} p<0.05 ;{ }^{* *} p<0.01 ;{ }^{* * *} p<0.001 ;{ }^{* * * *} p<0.10$. 
BBR

15,3

The control variables sector and experience did not present statistical significance in the relations established in the investigation. Access to the externalities of a cluster facilitates the activity of the subsidiaries as they are incorporated into the cluster. Thus, the greater the access to resources, the smaller the effects of DI and the better the performance results. These findings corroborate the research by Zaheer and Mosakowski (1997). The logic of subsidiaries clustering has already been researched by Diez-Vial (2011) in a developed economy in the southwest of Spain, and the results confirm a positive relation with the performance. In emerging markets, Meyer et al.(2009) found that the entry strategy adopted by the MNC is directly influenced by the institutions of the host country and by the availability of local resources. Although the study deals with an emerging country, the results of access to cluster resources we did not investigate in relation to performance.

Model 2 of Table 3 confirms hypotheses $\mathrm{H}_{4}$ and $\mathrm{H}_{6}$. This shows that greater access to cluster resources by subsidiaries is positively related to performance. In addition, model 5 of the same Table, analyzing an interaction relation, reveals positive effect of cluster resources on the relationship between ID and performance. The perspective of non-efficiency of subsidiaries in the host country may have the detrimental effects of ID moderated by cluster resources, consequently, better performance by benefiting from cluster externalities (BOSCHMA, 2005). We verified, according to the sample, that cluster resources have a mitigating effect on the relation of ID on performance. We also emphasize that ID is better perceived through the interaction factor of cluster resources.

The entry mode is related to the impact of the institutions of the host country. Thus, the literature generally recommends that the greater the distance between countries, the preferential entry mode strategy is of lower capital representation. Empirical studies have focused their research on developed economies and have divergent results. The research by Mayer et al. (2009) in emerging markets also relates to the impact of institutions and the availability of resources; however, the entry modes follow most of the empirical results that analyzed the institutional framework. When the institutional framework is weak, the entry mode through joint venture is the preferential one to provide access to the market. The results of models 3 and 4 of Table 3 show an inverse relationship. The results, even though they were not statistically significant, reveal that modes of entry with less capital representation imply worse performance than those of the subsidiaries that entered through greenfield. Similar results were found in Thailand, in which the greenfield business venture tends to have a performance profile superior to that of the business ventures via a joint venture (SIRIPAISALPIPAT; HOSHINO, 2000).

The interaction effect of the entry mode on the ID relation in the performance did not present statistical significance; however, it reveals that ID has a negative moderating effect on performance, i.e., the entry mode via greenfield tends to have superior interaction in the relationship between ID and performance when compared to a joint venture. Therefore, hypothesis $\mathrm{H}_{2}$ was confirmed, and hypotheses $\mathrm{H}_{3}$ and $\mathrm{H}_{5}$ were not.

The model with two interaction variables in the relationship between ID and performance is represented in model 6 of Table 3. We did not find studies that tested the model. The results show that the model is statistically significant. However, the findings reinforce that MNCs, when accessing cluster resources, will minimize the effects of ID and will adopt greenfield entry strategies as a way to guarantee better performance. Access to cluster resources can overcome weaknesses in the institutional framework and MNC exposure to the enormous challenges of managing an acquired or shared business. Thus, $\mathrm{H}_{7}$ is confirmed by the information provided by the sample data.

The perspective of the choice of the entry mode as a way to mitigate the effects of ID is contradicted in this research. The results show that the choice of the entry mode is not enough to soften the effects of ID. The answer is in the proximity of the companies and in the access of the context of externalities of the business environment. Access to 
cluster resources contributes to overcoming the fragility of the institutional framework and encourages MNCs to adopt an entry mode with full control of their subsidiaries. This result represents a rupture in the empirical studies, which suggests that in weak institutional frameworks MNCs adopt entries through joint venture (ZHAO; LUO; SUH, 2004; LUIZ; RUPLAL, 2013). The result presents a new answer for most existing literature, in particular, that access to clusters resources in an emerging market minimizes the effects of ID and encourages MNCs to adopt strategies for full control of their subsidiaries.

The findings contradict some studies (MEYER et al., 2009, among others), but broaden the discussion on the behavior of MNCs in emerging economies. ID is no longer seen as a constraint, since the entry strategy reveals that in emerging economies such as Brazil, MNCs, when accessing cluster resources, adopt greenfield entry strategies as a form of protection and assurance by the institutional context in the host country.

\section{Additional Analysis and Robustness}

To examine the results in more depth, we performed some additional tests and robustness tests. First, the theoretical part of the research is concentrated on ID diversities as a source of greater complexity in the performance of foreign subsidiaries, therefore, ID acts as a negative factor in the relationship with performance. Therefore, the perception of ID by the foreign subsidiaries that adopted the greenfield entry mode in Brazil ( $\beta-0.104$ is not the same as the companies that entered via joint ventures $\left(\beta-0.154^{*}\right)$ or via business acquisition. The different perceptions of ID for different entry modes in the host country show us that foreign subsidiaries deal with additional costs according to perceived institutional difference. In other words, the LOF and institutional contexts that foreign subsidiaries find can increase transaction costs and even make activities in the host country unfeasible (BUCKLEY, 2002; ENDO; OZAKI; ANDO, 2014).

If we analyze the perception of the ID of the foreign subsidiaries that are inserted in a cluster ( $\beta$ 0.053) and companies that are not in industrial proximities $(\beta-0.261, p<0.001)$ and do not benefit from cluster externalities, we will see that the results corroborate the idea of additional costs that result in competitive disadvantage for the MNCs in subsidiaries (ZAHEER, 1995; HALASZOVICH; LUNDAN, 2016). These costs are due to the institutional differences between countries with higher costs of adaptation and monitoring (LU; BEAMISH, 2001). Therefore, the MNC will prefer less representative entry modes of capital as a joint venture entry (ZHAO; LUO; SUH, 2004).

\section{FINAL CONSIDERATIONS}

Our research aimed to investigate the moderating effects of cluster resources and the strategies of the entry modes on the relation of ID on the performance of the foreign subsidiaries in Brazil. Theoretical relationships were analyzed and tested under multiple regression. The results show that ID is statistically significant in relation to performance, and their perception reveals that even with extensive experience in the host country, ID continues to have a negative relationship. However, if we add interaction factors in the relationship between ID and performance, the effect of ID is mitigated. Thus, weak institutional frameworks require interaction factors so that ID can be attenuated and present a positive relationship in performance.

Access to proximity resources resulting from a cluster suggests important changes to the view that ID can be managed by the strategies of entry into a host country. Although the study provided an initial investigation, it should be noted that more research needs to be done to analyze the entry strategy with wholly owned subsidiaries. Future research need to explore the specific advantages of the MNC and the specific advantages of the host country, which was a limitation of this study. The results require further research to corroborate the 
BBR

15,3 findings. This study represents the first attempt to examine the moderating effects of cluster resources and entry modes in the relationship of ID with the performance of subsidiaries. We hope that other studies will examine the same interactions in the relationship so that the results broaden the discussion including different emerging countries.

In addition to the contextual efforts presented, the findings reinforce the idea that public policies need to create mechanisms to promote and strengthen clusters. Promoting and strengthening clusters can be an effective way to attract more FDIs and improve the country's economic performance. This means that strengthened clusters will attract more FDI because they present prudential mechanisms to control the effects of ID.

The results refer to two important theoretical implications. First, in countries with fragile institutional environments, the choice of subnational location and the entry mode via greenfield are associated with accessing the externalities of an existing cluster. Thus, it is contrary to the idea that in institutional environments with a high dissociative degree MNCs adopt strategies of lower asset impairment, as entry via joint venture. Second, in institutional environments of developing economies, it is not always possible to affirm that ID decreases with time; there is a need for an interaction factor (clusters resources) in the relationship so that we can better understand the effects of ID.

\section{REFERENCES}

AMBOS, B.; HÅKANSON, L. The concept of distance in international management research. Journal of International Management, v. 20, n. 1, p. 1-7, 2014.

ANDERSSON, Ulf; FORSGREN, Mats; HOLM, Ulf. The strategic impact of external networks: subsidiary performance and competence development in the multinational corporation. Strategic management journal, v. 23, n. 11, p. 979-996, 2002.

BACEN. Banco Central do Brasil. Censo de Capitais Estrangeiros no País. Banco Central do Brasil, 2010.

BALLAND, P. A.; DE VAAN, M.; BOSCHMA, R. The dynamics of interfirm networks along the industry life cycle: The case of the global video game industry, 1987-2007. Journal of Economic Geography, v. 13, n. 5, p. 741-765, 2013.

BERRY, H.; GUILLÉN, M. F.; ZHOU, N. An institutional approach to cross-national distance. Journal of International Business Studies, v. 41, n. 9, p. 1460-1480, 2010.

BOSCHMA, R. A. Proximity and innovation: a critical assessment. Regional studies, v. 39, n. 1, p. 61-74, 2005.

BOSCHMA, R. A.; FRENKEN, K. Why is economic geography not an evolutionary science? Towards an evolutionary economic geography. Journal of economic geography, v. 6, n. 3, p. 273-302, 2006.

BUCKLEY, P. J. Is the international business research agenda running out of steam? Journal of international business studies, v. 33, n. 2, p. 365-373, 2002.

DIEZ-VIAL, I. Geographical cluster and performance: The case of Iberian ham. Food Policy, v. 36, n. 4, p. 517-525, 2011.

DIKOVA, D.; VAN WITTELOOSTUIJN, A. Foreign direct investment mode choice: entry and establishment modes in transition economies. Journal of international business studies, v. 38, n. 6, p. 1013-1033, 2007.

DIMAGGIO, P. J.; POWELL, W. W. The iron cage revisited institutional isomorphism and collective rationality in organizational fields. American Sociological Review, v. 48, n. 2, p. 147-160, 1983.

EDEN, L.;MILLER, S. R. Distance matters: Liability of foreignness, institutional distance and ownership strategy. In:HITT, M. A., Cheng, J. L. (Ed.) Advances in International Management.New York: Elsevier, 2004. pp. 187-222).

ENDO, N.;OZAKI, T.;ANDO, N. (2014). Firm-level Factor Versus National Institutional Difference: Ownership Structure in a Foreign Subsidiary of a Japanese Logistics Firm. The Asian Journal of Shipping and Logistics, v. 30, n.3, p. 393-413, 2014.

FISCH, J. H. Information costs and internationalization performance. Global Strategy Journal, v.2, n.4, p. 296-312, 2012.

GHOSHAL, S.;NOHRIA, N. Internal differentiation within multinational corporations. Strategic management journal, v. 10, n. 4, p. 323-337, 1989.

HAIR, J. F. et al. Análise multivariada de dados. Porto Alegre: Bookman, 2009. 
HALASZOVICH, T. F.;LUNDAN, S. M. (2016). The moderating role of local embeddedness on the performance of foreign and domestic firms in emerging markets. International Business Review, v. 25, n. 5, p. 1136-1148, 2016.

HAMANN, P. M. et al.Exploring the dimensions of organizational performance a construct validity study. Organizational Research Methods, v.16, n. 1, p. 67-87, 2013.

HANSEN, G. S.;WERNERFELT, B. Determinants of firm performance: The relative importance of economic and organizational factors. Strategic management journal, v. 10, n. 5, p. 399-411, 1989.

HENNART, J. F.;SLANGEN, A. H. Yes, we really do need more entry mode studies! A commentary on Shaver. Journal of International Business Studies, v. 46, n. 1, p. 114-122, 2015.

HOLM, U.;JOHANSON, J.;THILENIUS, P. (2015). Headquarters' Knowledge of Subsidiary Network Contexts in the Multinational Corporation. In: FORSGREN, M.; HOLM, U.; JOHANSON, J. (eds.). Knowledge, Networks and Power. UK: Palgrave Macmillan, 2015. pp. 245-263.

HOSPERS, G. J.;BEUGELSDIJK, S. Regional cluster policies: learning by comparing? Kyklos, v. 55, n. 3, p. 381-402, 2002.

KNOBEN, J.;OERLEMANS, L. A. Proximity and inter-organizational collaboration: A literature review. International Journal of Management Reviews, v. 8, n. 2, p. 71-89, 2006.

KOSTOVA, T. Country institutional profiles: Concept and measurement. Academy of Management Proceedings,n. 1, p. 180-184, 1997.

KOSTOVA, T.;ROTH, K.;DACIN, M. T. Institutional theory in the study of multinational corporations: A critique and new directions. Academy of management review, v. 33, n. 4, p. 994-1006, 2008.

KRETSCHMER, K. Performance evaluation of foreign subsidiaries. Wiesbaden: mir-Edition, 2008.

LARIMO, J.; Le Nguyen, H.;ALI, T. Performance measurement choices in international joint ventures: What factors drive them? Journal of Business Research, v. 69, n. 2, p. 877-887, 2016.

LAZZERETTI, L.;CAPONE, F. (2016). How proximity matters in innovation networks dynamics along the cluster evolution. A study of the high technology applied to cultural goods. Journal of Business Research, v. 69, n. 12 , p. $5855-5865,2016$.

LENZ, R. T. 'Determinants' of organizational performance: An interdisciplinary review. Strategic Management Journal, v. 2, n. 2, p. 131-154, 1981.

LIAO, T. J. Local clusters of SOEs, POEs, and FIEs, international experience, and the performance of foreign firms operating in emerging economies. International Business Review, v. 24, n. 1, p. 66-76, 2015.

LIU, X. et al. Environmental risks, localization and the overseas subsidiary performance of MNEs from an emerging economy. Journal of World Business, v. 51, n. 3, p. 356-368, 2016.

LU, J. W.;BEAMISH, P. W. The internationalization and performance of SMEs. Strategic management journal, v. 22, n. 6-7, p. 565-586, 2001.

LUIZ, J. M.;RUPLAL, M. Foreign direct investment, institutional voids, and the internationalization of mining companies into Africa. Emerging Markets Finance and Trade, v. 49, n. 4, p. 113-129, 2013.

LUO, Y.;SHENKAR, O.;NYAW, M. K. Mitigating liabilities of foreignness: Defensive versus offensive approaches. Journal of International Management, v. 8, n. 3, p. 283-300, 2002.

MAROCO, J. AnáliseEstatística com o SPSS Statistics. 5.ed. Pero Pinheiro: Report Number, 2011.

MARSHALL, A. (1890). Principles of economics: an introductory volume. London: Macmillan, 1890.

MEYER, K. E. et al.Institutions, resources, and entry strategies in emerging economies. Strategic management journal, v. 30, n. 1, p. 61-80, 2009.

MILLER, C. C.;WASHBURN, N. T.;GLICK, W. H. Perspective-The myth of firm performance. Organization Science, v. 24, n. 3, p. 948-964, 2013.

MOLINA-MORALES, F. X.;GARCÍA-VILLAVERDE, P. M.;PARRA-REQUENA, G. Geographical and cognitive proximity effects on innovation performance in SMEs: a way through knowledge acquisition. International Entrepreneurship and Management Journal, v. 10, n. 2, p. 231-251, 2014.

NACHUM, L. Liability of Foreignness. In: AUGIER, M; TEECE, D. (eds.). The Palgrave Encyclopedia of Strategic Management.London: Palgrave Macmillan, 2014. pp. 1-3.

PORTER, M. E. Competição. Edição revista e ampliada. Rio de Janeiro: Campus, 2009.

PRIM, A. L.;AMAL, M.;CARVALHO, L.Regional Cluster, InnovationandExport Performance: AnEmpiricalStudy. BAR-Brazilian Administration Review, v. 13, n. 2, p. 1-26, 2016.

QIAN, G.;LI, L.;RUGMAN, A. M. Liability of country foreignness and liability of regional foreignness: Their effects on geographic diversification and firm performance. Journal of International Business Studies, v. 44, n. 6, p. 635-647, 2013.

ROOT, F. R. Entry strategies for international markets. New York: Lexington Books, 1994. 
BBR

15,3
ROSENBUSCH, N.;RAUCH, A.;BAUSCH, A. The mediating role of entrepreneurial orientation in the task environment-performance relationship A meta-analysis. Journal of Management, v. 39, n. 3, p. 633-659, 2013.

ROSENZWEIG, P. M.; Singh, J. V. Organizational environments and the multinational enterprise. Academy of Management review, v. 16, n. 2, p. 340-361, 1991.

SCOTT, W. R. Institutions and organizations: Ideas, interests, and identities. Thousand Oaks: Sage, 2014.

SHRADER, R. C.;OVIATT, B. M.;MCDOUGALL, P. P. (2000). How new ventures exploit trade-offs among international risk factors: Lessons for the accelerated internationization of the 21 st century. Academy of Management Journal, v. 43, n. 6, p. 1227-1247, 2000.

SIRIPAISALPIPAT, P.;HOSHINO, Y.Firm-specific advantages, entry modes, and performance of Japanese FDI in Thailand. Japan and the World Economy, v. 12, n. 1, p. 33-48, 2000.

SLANGEN, A. H.; BEUGELSDIJK, S. The impact of institutional hazards on foreign multinational activity: A contingency perspective. Journal of International Business Studies, v. 41, n. 6, p. 980-995, 2010.

SURDU, I.;MELLAHI, K. Theoretical foundations of equity based foreign market entry decisions: A review of the literature and recommendations for future research. International Business Review, v. 25, n. 5, p. 1169-1184, 2016.

TANG, J.; ROWE, W. G. The liability of closeness: Business relatedness and foreign subsidiary performance. Journal of World Business, v. 47, n. 2, p. 288-296, 2012.

TOMIO, B. T.;AMAL, M. Institutional Distance and Brazilian Outward Foreign Direct Investment. management-aims, v. 18, n. 1, p. 78-101, 2015.

TORRE, A.; WALLET, F. Introduction: the role of proximity relations in regional and territorial development processes. TORRE, A.;WALLET, F. (Eds.). Regional development and proximity relations. Cheltenham: Edward Elgar, 2014.pp. 1-44.

UNCTAD. World Investment Report 2014: Investing in the SDGs: An Action Plan. New York and Geneva: United Nations, 2015.

YANG, Z.;SU, C. Institutional theory in business marketing: A conceptual framework and future directions. Industrial Marketing Management, v. 43, n. 5, p. 721-725, 2014.

ZAHEER, S. Overcoming the liability of foreignness. Academy of Management journal, v. 38, n. 2, p. 341$363,1995$.

ZAHEER, S.The liability of foreignness, redux: A commentary. Journal of International Management, v. 8, n. 3, p. 351-358, 2002.

ZAHEER, S.;MOSAKOWSKI, E. The dynamics of the liability of foreignness: A global study of survival in financial services. Strategic management journal, v. 18, n. 6, p. 439-463, 1997.

ZHANG, Y. A.;LI, Y.;LI, H. FDI spillovers over time in an emerging market: The roles of entry tenure and barriers to imitation. Academy of Management Journal, v. 57, n. 3, p. 698-722, 2014.

ZHAO, H.;LUO, Y.; SUH, T. Transaction cost determinants and ownership-based entry mode choice: A metaanalytical review. Journal of international business studies, v. 35, n. 6, p. 524-544, 2004. 